pedahohiky, psykholohii pratsi y andrahohiky [Vocational training problems at production site in the context of pedagogy, work psychology and andragogy]. Profesijne navchannya na vyrobnycztvi: zb. nauk. prats. Kyiv: Vyd. Instytutu profesijno-texnichnoyi osvity NAPN Ukrayiny, 6-17 [in Ukrainian]

Polozhennia pro orhanizatsiiu navchalno-vyrobnychoho protsesu na vyrobnytstvi [Regulations on the organization of the training and production process in industries] (2006, as amended in 2017). URL: https://zakon.rada.gov.ua/laws/show/z0032-07 [in Ukrainian]

Polozhennia pro profesiine navchannia kadriv na vyrobnytstvi [Regulations on staff's professional training in industries] (2001, as amended in 2018). URL: https://zakon.rada.gov.ua/laws/show/z0315-01 [in Ukrainian]

Radkevych, V. (2011). Suchasni chynnyky rozvytku profesiinoho navchannia $v$ umovakh vyrobnytstva [Modern professional training development factors under the conditions of production.]. Profesijne navchannya na vyrobnycztvi: zb. nauk. prats. Kyiv: Vyd. Instytutu profesijno-texnichnoyi osvity NAPN Ukrayiny, 18-27 [in Ukrainian]

Svystun, V.I. (2012). Pedahohichni umovy profesiinoho navchannia personalu na vyrobnytstvi [Pedagogical conditions of staff's professional training in industries]. URL: http://lib.iitta.gov.ua/id/eprint/2719 [in Ukraine]

Lukyanova, L.B., Anishchenko, O.V., Sigaeva, L.E., Zinchenko, S.V., Banit, O.V., Doroshenko, N.I. (2013). Suchasni tekhnolohii osvity doroslykh [Modern technologies of adult education]. Kirovograd: Imex-LTD [in Ukrainian]

Vovk, M., Khodakivska, S. (2019). Tekhnolohii navchannia doroslykh $v$ umovakh formalnoi i neformalnoi osvity [Technologies of adult learning in formal and non-formal education]. DOI: https://doi.org/10.35387/od.2(16).2019.39-48 [in Ukraine]

Dustmann. C, Schönberg, U. (2012). What makes firm-based vocational training schemes successful? The role of commitment. Am Econ J 4(2): 36-61 [in English]

УДК 61:374.72

DOI: https://doi.org/10.35387/od.1(17).2020.97-105

Філатов Андрій Олександрович - аспірант Київського національного лінгвістичного університету

ORCID iD: https://orcid.org/0000-0002-1921-213X

E-mail: andriy.a.filatov@gmail.com

\title{
ДО ПИТАННЯ ПРО НЕФОРМАЛЬНУ ОСВІТУ ФАХІВЦІВ У СФЕРІ ОХОРОНИ ЗДОРОВ'Я (НА ПРИКЛАДІ КОРПОРАТИВНОГО НАВЧАННЯ)
}

Анотація. В оглядовій статті проаналізовано окремі аспекти проблеми неформальної корпоративної освіти фрахівців у галузі охорони здоров'я. Визначено необхідність впровадження корпоративної колаборації у сфреру підвищення кваліфікації лікарів і медичних працівників. Виокремлено завдання, що потребують вирішення: кваліфікована 
поінформованість відповідальних осіб за надання сучасних медичних послуг; застаріла інфраструктура організації й надання медичних послуг різним категоріям дорослого населення; недостатнє фрінансування медичних інновацій. Узагальнено розуміння корпоративної колаборації як процесу співробітництва, кооперації, сумісної діяльності (взаємодії) двох і більш елементів соціально-економічної системи, що основані на обміні інфрормацією $i$ самонавчанні, а iї результатом $\epsilon$ досягнення синергетичного ефректу за заданими параметрами. З'ясовано, що зміст навчальних програм з підвищення кваліфікації має враховувати ряд ключових аспектів освіти дорослих: проведення тренінгів, короткотермінових курсів для ефрективного засвоєння нових знань $i$ формування відповідних навичок. На часі - розроблення процедури, механізмів оцінювання, визнання результатів навчання медичного персоналу в умовах неформальної освіти. Доведено, що оскільки під впливом динамічних глобалізаційних процесів, що відбуваються у світі, нефрормальна корпоративна медична освіта як складник освіти дорослих набуває специфічних рис, доцільно докорінним чином змінити сфреру корпоративної освіти лікарів $і$ медичних працівників, перевести ії у формат неформальної освіти дорослих, яка тепер реалізується не лише в традиційній аудиторній, а й у дистанційній та змішаній формах навчання, $i$, серед інших переваг, забезпечує економію коштів, більший доступ до навчання тощо.

Ключові слова: освіта дорослих; неформальна освіта; корпоративна освіта; підвищення кваліфікації; колаборація; медичні працівники; охорона здоров'я. University

Filatov Andrii - Postgraduate Student of the Kyiv National Linguistic ORCID iD: https://orcid.org/0000-0002-1921-213X

E-mail: andriy.a.filatov@gmail.com

\section{ON THE QUESTION OF NON-FORMAL EDUCATION OF PROFESSIONALS IN THE FIELD OF HEALTH CARE (ON THE EXAMPLE OF CORPORATE TRAINING)}

Abstract. The review article analyzes some aspects of the problem of non-formal corporate education of the professionals in the field of health care. The necessity of introduction of corporate collaboration in the field of professional development of doctors and medical workers is determined. The tasks that need to be solved are identified: qualified awareness of those responsible for the provision of modern medical services; outdated infrastructure of organization and provision of medical services to various categories of the adults; insufficient funding for medical innovations. It is generalized the understanding of corporate collaboration as a process of cooperation, collaboration, joint activity (interaction) of two or more elements of the socio-economic system, based on information exchange and self-study, and 
its result is to achieve a synergistic effect on given parameters. It was found that the content of training programs should take into account a number of key aspects of adult education:conducting trainings, short-term courses for the effective acquisition of new knowledge and the formation of relevant skills. It is time now to develop a procedure, mechanisms for evaluation, recognition of the results of training of medical staff in non-formal education. It is proved that since under the influence of dynamic globalization processes taking place in the world, the non-formal corporate medical education as a component of adult education acquires specific features, it is expedient to radically change the field of corporate education of doctors and health workers, transform it into the format of non-formal adult education, which is now implemented not only in the traditional classroom, but also in distance and blended forms of learning, and that, among other benefits, provides funds savings, greater access to learning and more.

Key words: adult education; non-formal education; corporate education; professional development; collaboration; medical workers; health care.

Постановка проблеми, її актуальність. Соціально-політичні та економічні зміни, що відбулися в суспільстві на початку XXI ст., у поєднанні 3 науково-технологічними трансформаціями, стали провідними детермінантами, які суттєво вплинули на визначення ролі корпоративної освіти у сучасному українському соціумі.

Наголосимо, що з огляду на демографічну ситуацію в Україні, важливим для країни $€$ вирішення проблеми залучення різних категорій дорослого населення до освіти впродовж життя. На нашу думку, це зумовлено зміною форм соціально-економічного життя, швидкою застарілістю наукової і професійної інформації, труднощами міжгенераційної взаємодії, потребою інтеграції людей поважного віку в сучасне суспільство, що в свою чергу зумовлює неперервність освіти, її вихід за вікові межі та забезпечує адаптацію людей дорослого віку в новий етап життя.

Теоретичний аналіз світового досвіду неформальної освіти дорослих засвідчує наявність широкого спектру освітніх послуг для цієї вікової категорії населення країни, важливість їх значення для розвитку особистісного й професійного потенціалу українських громадян. Проте, в Україні існуюче розмаїття освітньої діяльності для дорослих, на жаль, не може бути схарактеризоване як цілісна система освіти для дорослих, оскільки всі заклади та установи існують розрізнено та об'єднані лише в рамках проектної діяльності або на громадських засадах волонтерів.

Аналіз останніх досліджень і публікацій. Для нашого наукового пошуку важливе значення мають результати досліджень неперервної освіти і навчання в контексті освіти впродовж життя (С. Гончаренко, О. Дубасенюк, Н. Ничкало, О. Щербак та ін.), теорії і методики формальної, неформальної освіти дорослих (С. Бабушко, О. Василенко, С. Вершловський та ін.), післядипломної освіти (О. Пехота, Т. Сорочан та 
ін.), проблем корпоративної освіти (І. Литовченко, Н. Пазюра, Т. Дейвенпорт (Т. Davenport), П. Друкер (P. Drucker) та ін.). Незважаючи на досить широке коло аналізованих науковцями проблем формальної і неформальної освіти та практики корпоративного навчання, цілісне висвітлення особливостей розвитку корпоративної освіти як складової освіти дорослих в Україні не набуло статусу комплексних наукових досліджень, що й зумовило вибір проблематики наукового пошуку.

Проблемам неформальної освіти дорослих як освітнього тренду XXI століття присвячено наукові праці відомих українських дослідників: О. Аніщенко, О. Баніт, О. Волярської, Л. Лук'янової, С. Прийми та ін. На думку вчених, для України актуальність неформальної освіти дорослого населення зумовлена такими чинниками, як: труднощі адаптації дорослих до нових соціальних та економічних умов розвитку країни, зростання безробіття, вимушена міграція працездатного населення, зростання кількості внутрішньо переміщених осіб; втрата кваліфікаційних характеристик дорослих та відсутність необхідних професійних компетенцій персоналу підприємств, організацій та установ в умовах конкуренції на ринку праці.

Так, науковці у сфрері освіти дорослих О. Аніщенко, Л. Лук'янова, С. Прийма зазначають, що впродовж «двох останніх десятиліть освіта дорослих як складова навчання впродовж життя..., неперервної освіти $€$ визначальною метою політики у сфері освіти розвинених країн на національному і міжнародному рівнях» (Аніщенко, Лук'янова, Прийма, 2017, c. 3).

За О. Баніт, «підготовка та підвищення кваліфікації персоналу залишається прерогативою великих підприємств...Однак, при всіх зазначених перевагах варто зауважити, що корпоративна освіта ... має свої межі ефрективності. Ї̈̈ ефрективність обмежена рівнем компетенції та інтересів працюючих «усередині системи» співробітників. Тому найбільш ефективним рішенням $\epsilon$ використання як внутрішньої системи корпоративної освіти, так і партнерської співпраці з однією або кількома бізнес-школами (Баніт, 2018, с.183).

Як свідчить дослідження О. Волярської, у контексті розвитку неформальної української медичної освіти набуває актуальності «потреба вивчення досвіду медичної освіти дорослого населення в закладах та установах неформальної освіти, які існують в Україні» (Волярська, 2019, с. 75). Ми погоджуємося з думкою вченої, так на кінець 2019 р. в Україні нараховувалося понад 140 медичних асоціацій, громадських об'єднань, соціальних фондів, які здійснювали вагомий внесок у розбудову охорони здоров'я нашої країни. Представники цих закладів й установ проводили вебінари, пленуми, конференції, видавали журнали, займалися громадською діяльністю з медичного просвітництва дорослого населення. У зв'язку з цим, набуває актуальності неформальна медична освіта для такої категорії як лікарі.

Незважаючи на широке коло досліджень в галузі неформальної освіти та позитивні зрушення, які відбуваються в законодавчому полі, 
перед провайдерами освітніх послуг продовжує існувати ряд проблем пов'язаних 3 відсутністю інформацією, яка б формувала у них чітке розуміння щодо освітніх потреб в сфері охорони здоров'я різних груп дорослого населення, визначенню причин, які заважають дорослим долучатися до освітнього процесу в умовах неформальної освіти.

У психолого-педагогічній літературі нами не виявлено праць, присвячених розгляду специфріки медичної освіти лікарів в структурі неформальної освіти дорослих в Україні. Як наслідок залишаються недостатньо з'ясованими зміст, форми і методи неформальної корпоративної медичної освіти. Високо оцінуючи здобутки українських учених, зазначимо, що в українській корпоративній освіті відсутні комплексні дослідження, які присвячені організації і впровадженню неформальної медичної освіти лікарів як категорії дорослого населення.

Мета статті полягає в обґрунтуванні змісту неформальної корпоративної освіти фрахівців у галузі охорони здоров'я в Україні на прикладі сертифікації лікарів.

Виклад основного матеріалу дослідження. Серед нагальних завдань педагогічної науки і практики - створення центрів корпоративної освіти або альтернативної мережі закладів й установ неформальної освіти з підвищення кваліфікації, перепідготовки й сертифікації фахівців різних галузей виробництва. Доцільність створення зазначених центрів або закладів й установ передусім зумовлюється потребою розширенняактуалізація сфрери освітніх послуг для фахівців у контексті післядипломної освіти.

Акцентуємо увагу на тому, що ще у 1960 р. П. Друкер вводить терміни «інформаційна робота» та «інформаційний працівник», що може свідчити про те, що основою сучасного соціально-економічного розвитку країни є знання (Drucker, 2011). Як зазначає українська дослідниця проблем корпоративної освіти І.Литовченко, «основний капітал інформаційних працівників - це не знання, а їх вклад у компанію - це не фрізична праця, а знання про клієнтів чи інші професійні знання, якими вони володіють. Вони не просто виконують завдання, а розповсюджують знання та беруть участь в ухваленні рішень» (Литовченко, 2016, с. 179). Ми погоджуємося з авторкою, що новітні технології наближують навчання до реального життя. Інтернет, електронна пошта, мобільний зв'язок дають змогу фахівцям отримувати підвищення кваліфікації в будь-якому місці та в будь-який зручний для них час, миттєво встановлювати зв'язок із колегами.

Зазначимо, що в умовах суспільства знань науково-технічний прогрес, телекомунікаційні технології, чинять визначальний вплив на всі сфрери життя населення. Актуальність корпоративної освіти в галузі охорони здоров'я підвищується також з огляду на зростання мобільності трудових ресурсів.

Потужний поштовх до розвитку отримує післядипломна освіта й короткострокове підвищення кваліфікації фахівців. Особливо суттєві перетворення відбуваються в секторі медичних кваліфікацій, які мають 
швидко реагувати на потреби сучасних викликів у медицині. Зростають вимоги до лікарів, які повинні забезпечувати високу якість обслуговування пацієнтів та забезпечувати високу ефективність роботи медичної установи, а, відповідно, брати на себе відповідальність за власний професійний розвиток.

Вважаємо за доцільне зазначити, що наразі в Україні визначено основні організаційні засади безперервного професійного розвитку фахівців у сфері охорони здоров'я. Так, у Постанові Кабінету міністрів України «Положення про систему безперервного професійного розвитку фахівців у сфері охорони здоров'я» (Постанова Кабінету міністрів України, 2019) йдеться про безперервний професійний розвиток фахівців у сфері охорони здоров'я. У Наказі міністерства охорони здоров'я України «Деякі питання безперервного професійного розвитку лікарів» (Наказ міністерства охорони здоров'я України, 2019) обґрунтовано механізм проведення атестації лікарів з метою перевірки їхнього безперервного професійного розвитку.

На нашу думку, зазначене вище актуалізує нагальність створення сертифікаційних центрів для підвищення кваліфікації фахівців медичної сфери. Актуальність створення таких центрів, на наше переконання, пов'язана з тим, що в Україні на сьогодні спостерігається тенденції щодо інтенсивного розвитку медичних технологій і медичного обладнання, розширення можливостей отримання високої якості медичних послуг у клінічних закладах охорони здоров'я та в галузі телемедичних сервісів, але їх упровадження та ефективне використання сповільнюється передусім через недостатність професійної підготовленості лікарів до використання сучасних форм, методів і засобів діагностування й лікування пацієнтів.

Аналізуючи ситуацію, що склалася, нами виокремлено завдання, що потребують вирішення: 1) кваліфікована поінформованість відповідальних осіб за надання сучасних медичних послуг; 2) застаріла інфраструктура організації й надання медичних послуг різним категоріям дорослого населення; 3) недостане фінансування медичних інновацій. Вищенаведена нетипова для нашого інформаційного простору послідовність завдань полягає, у першу чергу, у бізнес-підходах до вирішення проблем у сучасних корпоративних інструментах щодо організації й надання медичних послуг різним категоріям населення.

Наведемо приклад корпоративної колаборації. Аналіз праць зарубіжних науковців (S. Downes (Downes, 2009), A. Thomson \& J. Perry (Thomson, Perry, 2006)) дозволив констатувати, що під корпоративною колаборацією слід розуміти процес співробітництва, кооперації, спільної діяльності (взаємодії) двох і більш елементів соціально-економічної системи, що основані на обміні інформацією і самонавчанні. Результатом такої колаборації $€$ досягнення синергетичного ефекту за заданими параметрами. У нашому дослідженні колаборацію будемо розуміти у контексті об'єднання корпоративних зусиль закладів охорони здоров'я і закладів освіти, та профрільних бізнес корпорацій.

За аналогією аналізу діяльності автовиробників нами було 
поділено цільову аудиторію провайдерів медичних послуг за неконкуруючими між собою сегментами та об'єднано їхні зусилля в межах напрямів надання послуг. Встановлено, що від кількості учасників залежить розподіл операційних витрат, що, в свою чергу, за такою ж пропорцією підвищує ефективність бізнесу в цілому: вигідність та пріоритетність надання коштів фінансовими установам дозволяє індексувати бізнес як високоліквідний та з мінімальними факторами ризиків. Якщо спробувати імплементувати ефективні бізнес-моделі в діяльність виробників медичного обладнання, операторів медичних сервісів для інформування населенні, то необхідно розуміти, що важливих зусиль потребує організація підготовки та підвищення кваліфікації медичного персоналу.

Зазначимо, що навчання медичного персоналу 3 належним моніторингом навчальних результатів, дозволить забезпечити оперативніший спосіб впровадження сучасних медичних сервісів на ринку медичних послуг. Бюджет такої освітньої ініціативи, на нашу думку, легко може сягати 20 \%-30 \% від загальної вартості надання медичних послуг 3 діагностики та лікування населення. Тому вищенаведена ініціатива потребує високого рівня організації, управління та міжгалузевих комунікацій, з метою оптимізації витрат, та залучення сторонніх фрінансових інструментів.

Покращення медичних послуг та впровадження прогресивних медичних сервісів для різних категорій дорослого населення, подолання недостатньої кваліфікації медичного персоналу на сьогодні $€$ актуальною проблемою не лише для медичного персоналу та пацієнтів, але і для виробників медичного обладнання, та провайдерів медичного сервісу. Поєднання спільних інтересів у форматі впровадження корпоративної колаборації може слугувати платформою для організації взаємодії спеціалізованого закладу освіти (або сертифікаційного центру) і представників медичних сервісів з метою удосконалення їхньої діяльності. На нашу думку, це дозволить вирішити ряд інфраструктурних питань та може знизити негативні фактори, що впливали на сповільнення технічного прогресу і як наслідок низький рівень медичних послуг для кінцевих споживачів - громадян України. Вирішення такого роду завдань могла би забезпечити фахова освітня установа з належними освітніми програмами для найбільш оперативного засвоєння нового теоретичного та практичного матеріалу працівниками медичних закладів й установ.

Зміст цих програм має враховувати ряд ключових аспектів для підвищення кваліфікації чи перекваліфікації дорослих: тренінгів, короткотермінових курсів для ефективного засвоєння нових знань та формування практичних навичок тощо. Обов'язковим повинно бути встановлення порядку оцінювання навчальних результатів медичного персоналу, які б влаштували виробників медичних сервісів та споживачів медичних послуг. На нашу думку, спільні методи роботи у форматі корпоративної колаборації (об'єднання зусиль) виробників, провайдерів, споживачів зможуть у рази підвищити ефективність надання якості медичних послуг різним категоріям дорослого населення, та зменшити 
вартість таких ініціатив шляхом об'єднання зусиль. Водночас, для фактичного підтвердження вищенаведеної пропозиції, необхідно провести пілотний, проект з належною статистичної перевіркою усіх бізнес-процесів у сфері надання медичних послуг дорослим, з перевіркою короткочасних та тривалих ефектів, від запровадження таких ініціатив.

Висновки і перспективи подальших досліджень. Таким чином, доведено, що неформальна корпоративна освіта фахівців у галузі охорони здоров'я в Україні на прикладі сертифікації лікарів повинна враховувати переваги корпоративної колаборації у контексті об'єднання закладів охорони здоров'я з закладами чи установами освіти, та виробникам сучасного медичного обладнання, саме в частині підвищення кваліфікаційного рівня. Оскільки під впливом динамічних глобалізаційних процесів, що відбуваються у світі, неформальна корпоративна медична освіта як складник освіти дорослих набуває специфічних рис, варто докорінним чином змінити сферу корпоративної освіти лікарів і медичних працівників, перевести ії̈ у формат неформальної освіти дорослих, яка тепер реалізується не лише в традиційній аудиторній, а й у дистанційній та змішаній формах, i, серед інших переваг, забезпечує економію коштів, ширший доступ до навчання.

Здійснене дослідження не вичерпує зазначеної проблеми вивчення змісту корпоративної освіти лікарів. У перспективі вважаємо за необхідне вивчити тенденції розвитку неформальної освіти дорослих у контексті євроінтеграційних процесів, а також проаналізувати нормативно-правове забезпечення розвитку корпоративної освіти медичних працівників в Україні.

\section{Список використаних джерел}

Аніщенко, О., Лук'янова, Л. \& Прийма, С. (2017). Неформальна освіта дорослих - освітній тренд XXI століття. Рідна школа, 11-12, 3-7.

Баніт, О. (2018). Бізнес-освіта в системі професійного розвитку топ-менеджерів міжнародних організацій. Освіта дорослих: теорія, досвід, перспективи, 1, 180-189.

Волярська, О. С. (2019). Неформальна медична освіта дорослих в Україні. Fundamental and applied researches in practice of leading scientific schools, 36 (6), 74-78. doi: 10.33531/farplss.2019.6.10.

Литовченко, І. М. (2016). Розвиток корпоративної освіти в контексті суспільства знань: американський досвід. Педагогіка формування творчої особистості у вищій і загальноосвітній школах, 50 (103), 178-183.

Постанова Кабінету міністрів України «Положення про систему безперервного професійного розвитку фахівців у сфері охорони здоров'я» від 28 березня 2019 р. №302. https://zakon.rada.gov.ua/laws/show/302-2018$\%$ D0\%BF\#Text

Наказ Міністерства охорони здоров'я України «Деякі питання безперервного професійного розвитку лікарів» від 22.02.2019 р. №446. https://zakon.rada.gov.ua/laws/show/z0293-19\#Text

Downes, S. (2009). The Cloud and Collaboration. Stephen Downes: Website, Jun 15. URL: http://www.downes.ca/post/51343 
Drucker, P. F. (2011). Post-capitalist society. London; New York: Routledge Taylor\&Francis Group, 204 p.

Thomson, A. M. \& Perry, J. L. (2006). Collaboration Processes: Inside the Black Box. Public Administration Review. 66. 1. P. 20-32.

\section{References (translated and transliterated)}

Anishchenko, O., Lukyanova, L. \& Priyma, S. (2017). Neformalna osvita doroslyh osvitnij trend XXI stolittya [Non-formal adult education is an educational trend of the 21st century]. Ridna shkola - Native School, 11-12, 3-7 [in Ukrainian].

Banit, O. (2018). Biznes-osvita v sy`stemi profesijnogo rozvy tku top-menedzheriv mizhnarodny'x organizacij [Business education in the system of professional development of top-managers of international organizations]. Osvita dorosly 'x: teoriya, dosvid, perspekty 'vy' - Adult Education: Theory, Experience, Prospects, 1, 180-189 [in Ukrainian].

Voliarska, O. (2019). Ne formalna medychna osvita doroslyh v Ukraini [Non-formal medical education of adults in Ukraine]. Fundamental and applied researches in practice of leading scientific schools, 36 (6), 74-78. doi: 10.33531/farplss.2019.6.10 [in Ukrainian].

Lytovchenko, I. (2016). Rozvytok korporatyvnoyi osvity v konteksti suspilstva znan: amerykanskyj dosvid [Development of corporate education in context of knowledge society: The American experience]. Pedagogika formuvannya tvorchoyi osobystosti u vyshhij i zagal'noosvitnij shkolax, 50 (103), 178183 [in Ukrainian].

Postanova Kabinetu ministriv Ukrayiny «Polozhennya pro systemu bezperervnogo profesijnogo rozvytku faxivciv u sferi oxorony zdorovya» vid 28 bereznya 2019 r. №302. [Resolution of the Cabinet of Ministers of Ukraine "Regulations on the system of continuous professional development of health care professionals" of March 28, 2019 №302] https://zakon.rada.gov.ua/laws/show/302-2018-\%D0\%BF\#Text [in Ukrainian].

Nakaz ministerstva oxorony`zdorov'ya Ukrayiny` «Deyaki py`tannya bezperervnogo profesijnogo rozvy'tku likariv» vid 22.02. 2019. №446. [Order of the Ministry of Health of Ukraine "Some issues of continuous professional development of doctors" dated 22.02.2019 №446] https://zakon.rada.gov.ua/laws/show/z0293-19\#Text [in Ukrainian].

Drucker, P. F. (2011). Post-capitalist society. London; New York : Routledge Taylor \& Francis Group, 204 [in English].

Downes, S. (2009, Jun 15). The Cloud and Collaboration. Stephen Downes: Website. Retrieved from http://www.downes.ca/post/51343 [in English]

Thomson, A. M., Perry, J. L. (2006). Collaboration Processes: Inside the Black Box. Public Administration Review, 66, 1, 20-32 [in English]. 